\title{
Eythroderma associated with secondary syphilis: A case report of unusual presentation and resurgence of the great imitator
}

Sekonder sifiliz ile ilișkili eritroderma: Olağandıșı bir sunum ve büyük taklitçinin yeniden canlanması ile ilgili bir rapor

\section{Raul Gerardo Mendez, ๑ Adriana Guadalupe Reyes Torres, ๑ Manuel Soria Orozco,} ๑ Marisol Ramirez Padilla

Universidad De Guadalajara, Dermatology Service of Civil Hospital of Guadalajara "Fray Antonio Alcalde", Guadalajara, Mexico

\begin{abstract}
Syphilis is a chronic infection caused by the spirochete Treponema pallidum. The wide range of clinical presentations of secondary syphilis has given it the nickname of "the great imitator". Erythroderma is a generalized inflammatory reaction of the skin secondary to a wide variety of causes; however, it is not considered a common cutaneous manifestation of syphilis. Here, we presented the case of a 74-year-old Hispanic man who presented to our clinic with a history of chronic recurrent erythroderma. His medical history was not relevant except for previous unprotected sexual intercourses. Extensive work up to determine the cause of erythroderma was performed, resulting in positive for syphilis infection. Subsequent treatment of syphilis infection resulted in erythroderma remission.
\end{abstract}

Keywords: Erythroderma, syphilis, simulator

Öz

Frengi, spirochete Treponema Pallidum'un neden olduğu kronik bir enfeksiyondur. İkincil sifilizin geniş klinik sunumları ona "büyük taklitçinin" lakabı kazandırdı. Eritroderma, derinin çok çeşitli nedenlere bağlı olarak ortaya çıkan genelleşmiş bir enflamatuvar reaksiyonudur, ancak, sifilizin ortak bir kütanöz tezahürü olarak kabul edilmez.

Burada, kliniğimize kronik tekrarlayan eritroderma öyküsü ile başvuran 74 yaşında bir i̇spanyol erkeğin olgusunu sunuyoruz. Önceden korunmasız cinsel ilişki dışında tıbbi geçmişi önemli değildi. Eritrodermanın nedenini belirlemek için kapsamlı çalışma sifiliz enfeksiyonu için pozitif sonuçlandı. Daha sonra sifiliz enfeksiyonunun tedavisi eritroderma remisyonuyla sonuçlandı.

Anahtar Kelimeler: Eritroderma, sifiliz, simülatör

\section{Introduction}

Syphilis is a chronic infection caused by the spirochete Treponema Pallidum. The wide range of clinical presentations of secondary syphilis has earned her the nickname of "the great imitator" or "the great simulator".

In 2017, a total of 30.644 cases of syphilis were reported in the United States (US), yielding a rate of 9.5 cases per 100.000 population. This rate represents a $10.5 \%$ increase compared with 2016, and a 72.7\% increase compared with $2013^{1}$. Erythroderma is a generalized inflammatory reaction of the skin secondary to a wide variety of causes. Its incidence has been estimated at 1 per 100.000 inhabitants per year ${ }^{2}$. Erythroderma is not considered a common cutaneous manifestation of syphilis. The most common causes of erythroderma include exacerbation of preexisting dermatoses, hypersensitivity to drugs, malignant hematological processes, infections and idiopathic causes ${ }^{3}$.

Address for Correspondence/Yazışma Adresi: Raul Gerardo Mendez MD, Universidad De Guadalajara, Dermatology Service of Civil Hospital of Guadalajara

"Fray Antonio Alcalde", Guadalajara, Mexico Phone: +526144881440 E-mail: drraulmendezf@outlook.com Received/Geliş Tarihi: 05.04.2019 Accepted/Kabul Tarihi: 14.05.2019 ORCID: orcid.org/0000-0002-5945-6593

CCopyright 2019 by Turkish Society of Dermatology and Venereology

Turkderm-Turkish Archives of Dermatology and Venereology published by Galenos Yayınevi. 
We did not find reports of erythrodermas caused or associated by syphilis in adults in the literature, we only found this association in two cases of congenital syphilis that manifested with erythema and generalized desquamation.

\section{Case Report}

A 74-year-old Hispanic man presented to our clinic with a four-month history of erythroderma. His past medical history was non-relevant except for previous unprotected sexual intercourses and penicillin allergy. The patient denied history of previous medications or skin diseases.

At examination, generalized, symmetric, polymorphic, pruritic erythema with lamellar, grayish scales were noted concordant with erythroderma. There was no involvement of mucous membranes (Figure 1).

Further interrogation, the patient referred associated myalgias, arthralgias and chills. The patient had received non-specific doses of corticosteroid orally in another institution with partial improvement. Work up to determine the cause of erythroderma was performed and prednisone $1 \mathrm{mg} / \mathrm{kg} /$ day was indicated. Work up included a punch biopsy, laboratory tests and computed tomography (CT) scan in order to rule out the possibility of underlaying malignancy.

In a 5-day follow-up consultation, the patient presented with a new dermatosis, at examination, countless, small, erythematous papules with red-violaceous base and well-defined borders were noted on face, anterior thorax, proximal regions of upper and lower limbs, with involvement of palms and soles (Figure 2,3).

A punch biopsy reported dermoepidermal necrosis and presence of perivascular plasma cells and lymphoytes.

Laboratory tests reported acute phase reactant elevation, mild acute kidney injury with filtration rate of $38 \mathrm{~mL} / \mathrm{min}$ and borderline leukocytosis with deviation to the left. Serology for hepatitis $C$ virus (HCV), HBV, human immunodeficiency virus (HIV), antineutrophil cytoplasmic antibodies, (p-ANCA, c-ANCA) and antinuclear antibodies were negative. The immunological panel presented normal complement (C4, C3). Thoraco-abdominal CT, bone marrow biopsy and prostate specific antigen were negative for malignancy. Qualitative venereal disease research laboratory treponemal test and Fta-Abs were positive. Prednisone was discontinued. Treatment was started with ceftriaxone due to penicillin allergy, 2 gr every 24 hours for 14 days showing remarkable clinical improvement with complete resolution of skin lesions, renal improvement and cease of symptoms in subsequent 48 hrs of treatment (Figure 4). Informed consent was obtained.

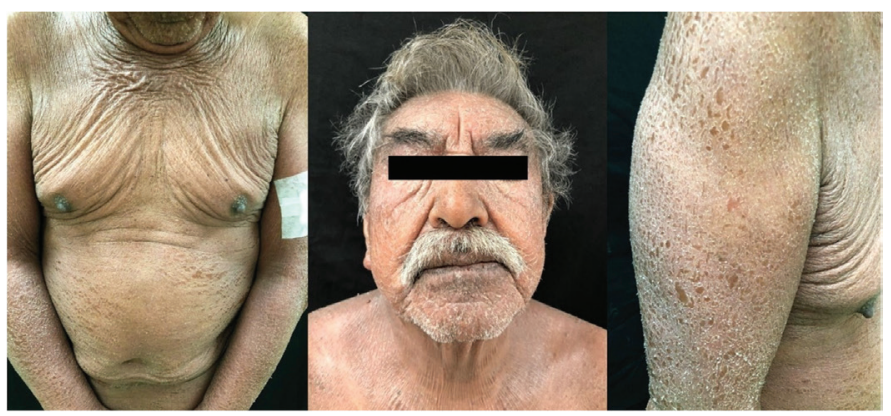

Figure 1. Generalized, symmetric, polymorphic, pruritic erythema with lamellar, grayish scales

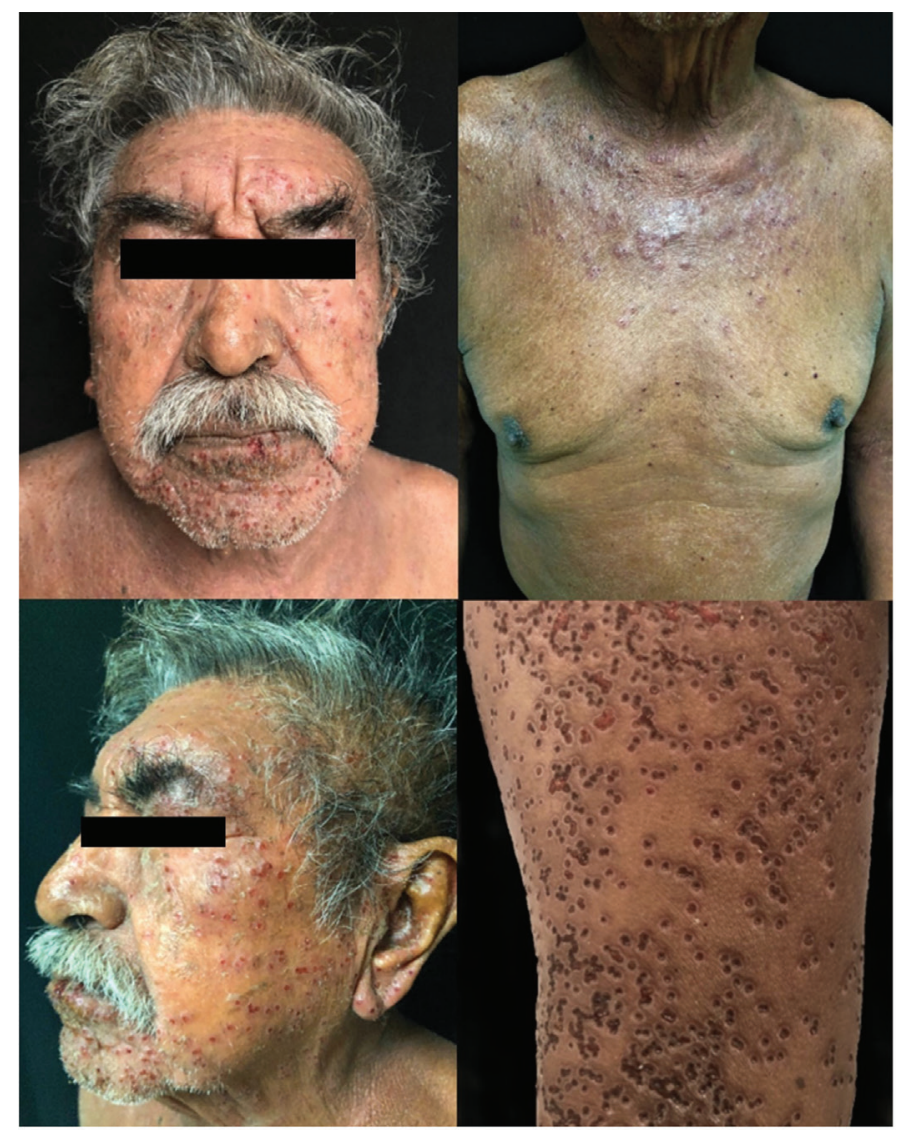

Figure 2. Multiple erythematous papules with red-violaceous base and well-defined borders on face, thorax and proximal regions of lower limbs

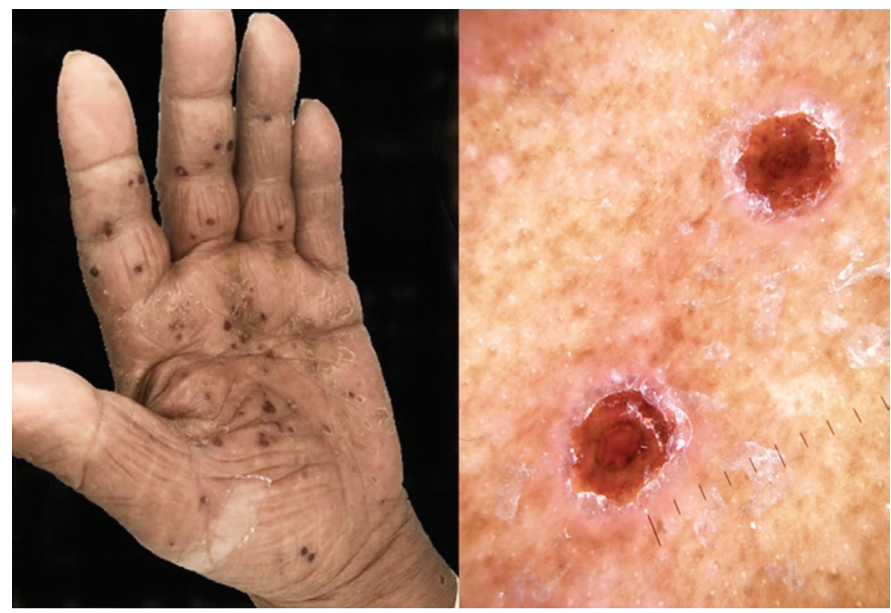

Figure 3. Palms and soles involvement; dermoscopy shows semicircular papules resembling a "volcanic fire ring"

\section{Discussion}

Erythroderma has multiple etiologies and it is a challenge for the dermatologist to identify them. Reports of erythroderma in adults related to secondary syphilis are limited and some associated with HIV. Co-infection of syphilis and HIV seems to alter the course of both diseases ${ }^{4}$. The cause of the massive recruitment of inflammatory cells in the skin of erythrodermic patients is of unknown origin and 


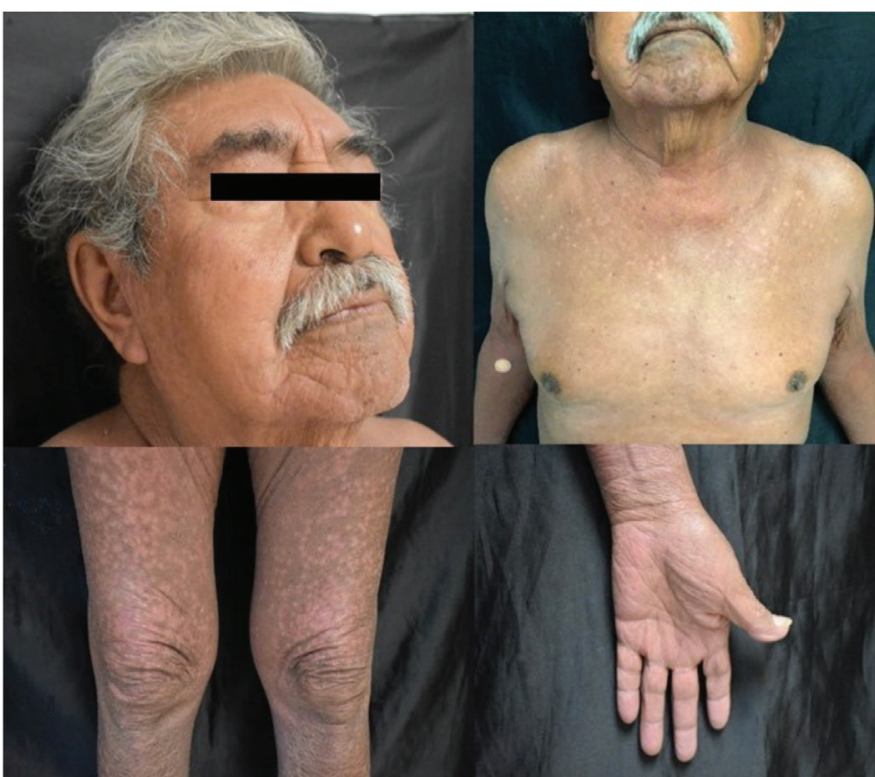

Figure 4. Clinical outcome after treatment with complete resolution of skin lesions and residurary hypochromic postinflamatory macules

the pathophysiological mechanism is different, depending on the cause. Inflammatory cells have also been shown in circulation. This inflammatory infiltrate causes an increase in epidermal turnover with the consequent erythematous and desquamative dermatosis that causes loss of proteins, fluids, electrolytes and nucleic acids ${ }^{5}$.

Estimations suggest that approximately $8 \%$ of cutaneous treponemic lesions demonstrate morphology and distributions suggestive of other dermatologic conditions, including atopic dermatitis, pityriasis rosea, psoriasis, drug-induced eruptions, erythema multiforme, mycosis fungoides, lichenoid lesions and far more uncommonly erythroderma, as in our case ${ }^{6}$.

It is important to remember that the histologic appearance of secondary syphilis can mimic many other diseases. Classically, in primary and secondary syphilis, skin biopsy shows central thinning or ulceration of the epidermal layer with heavy dermal lymphocyte infiltration including plasma cells, lymphovascular proliferation with endarteritis, small-vessel thrombosis, and dermal necrosis. Our patient's biopsy was compatible with these findings.

Approximately $25 \%$ of cases in the US of primary syphilis are not detected by non-treponemal testing, whereas a non-reactive test nearly always excludes a diagnosis of secondary or latent-stage syphilitic infection. Because of its high specificity, treponemal testing (which includes the fluorescent treponemal antibody absorption test) often is used to confirm diagnosis after positive screening with nontreponemal tests. Positive fluorescent treponemal antibody absorption testing and positive multiplex flow immunoassay may be used to confirm the diagnosis of T pallidum infection?7. Our patient had positive treponemal and non-treponemal tests.
The use of prednisone probably was a trigger that led to transient immunosuppression, that revealed more typical manifestations of syphilis infection, such as its presentation with papules, and palmar and plantar involvement.

The infection by T. pallidum is concluded as a trigger for erythroderma due to exhaustive discarding of other etiologies, and by confirmatory treponemal and non-treponemal tests, as well as a remarkable satisfactory clinical evolution once initiated the antibiotic treatment and complete resolution after completing the treatment.

It is important to remember the great clinical polymorphism that syphilis presents. The clinician should always suspect syphilis infection in patients with risk factors like our patient, by discarding other etiologies, or by characteristic dermatoses such as the involvement of palms and soles. The importance of early diagnosis lies in early treatment, patients who do not receive timely treatment are at risk of suffering major complications (e.g. tertiary syphilis) involving the central nervous system, cardiovascular structures, skin or bones.

\section{Ethics}

Informed Consent: Informed consent was obtained. Peer-review: Externally and internally peer-reviewed.

\section{Authorship Contributions}

Surgical and Medical Practices: R.G.M., A.G.R.T., M.S.O., M.R.P., Concept: R.G.M., A.G.R.T., M.S.O., M.R.P., Design: R.G.M., A.G.R.T., M.S.O., M.R.P., Data Collection or Processing: R.G.M., A.G.R.T., M.S.O., M.R.P., Analysis or Interpretation: R.G.M., A.G.R.T., M.S.O., M.R.P., Literature Search: R.G.M., A.G.R.T., M.S.O., M.R.P., Writing: R.G.M., A.G.R.T., M.S.O., M.R.P.

Conflict of Interest: No conflict of interest was declared by the authors.

Financial Disclosure: The authors declared that this study received no financial support.

\section{References}

1. STD Data and Statistics [Internet]. Cdc.gov. 2018 [cited 4 December 2018]. Available from: https://www.cdc.gov/std/stats/

2. Sigurdsson V, Toonstra J, Hezemans-Boer M, van Vloten WA: Erythroderma. A clinical and follow-up study of 102 patients, with special emphasis on survival. J Am Acad Dermatol 1996; 5:53-57.

3. Okoduwa C, Lambert WC, Schwartz RA, et al: Erythroderma: review of potentially life-threathening dermatosis. Indian J Dermatol 2009;54:1-6.

4. Tambe S, Zambare U, Nayak C: Nodulo-ulcerative and erythrodermic secondary syphilis in human immunodeficiency virus-infected individuals. Int J STD AIDS 2019:30:505-8.

5. Groves RW, Kapahi P, Barker JN, Haskard DO, MacDonald DM: Detection of circulating adhesion molecules in erythrodermic skin disease. J Am Acad Dermatol 1995;32:32-6.

6. Tang MBY, Yosipovitch G, Tan SH: Secondary syphilis presenting as a lichen planus-like rash. J Eur Acad Dermatol Venereol 2004;18:185-7.

7. Cervoni GE, By CC, Wesson SK: An Atypical Syphilis Presentation. Cutis 2017;100:E25-E8. 